\title{
Glacial vicariance in Eurasia: mitochondrial DNA evidence from Scots pine for a complex heritage involving genetically distinct refugia at mid-northern latitudes and in Asia Minor Krassimir Naydenov*1, Sauphie Senneville², Jean Beaulieu ${ }^{2,3}$, Francine Tremblay ${ }^{1}$ and Jean Bousquet ${ }^{2}$
}

\author{
Address: ${ }^{1}$ Chaire industrielle CRSNG-UQAT-UQAM, Université du Québec en Abitibi-Témiscamingue, 445 Bd. de l'Université, Rouyn-Noranda \\ (Québec), J9X 5E4, Canada, ${ }^{2}$ Chaire de recherche du Canada en génomique forestière et environnementale and Centre d'étude de la forêt, Pavillon \\ Charles-Eugène-Marchand, Université Laval, Québec (Québec), G1K 7P4, Canada and ${ }^{3}$ Natural Resources Canada, Canadian Forest Service, \\ Canadian Wood Fibre Centre, 1055 du PEPS, PO Box 10380, Stn. Sainte-Foy, Quebec (Quebec), G1V 4C7, Canada \\ Email: Krassimir Naydenov* - Krassimir.Naydenov@uqat.ca; Sauphie Senneville - sennevil@rsvs.ulaval.ca; \\ Jean Beaulieu - Jean.Beaulieu2@nrcan.gc.ca; Francine Tremblay - Francine.Tremblay@uqat.ca; Jean Bousquet - bousquet@rsvs.ulaval.ca \\ * Corresponding author
}

Published: 22 November 2007

BMC Evolutionary Biology 2007, 7:233 doi:10.1 I86/147|-2/48-7-233
Received: 2 March 2007

Accepted: 22 November 2007

This article is available from: http://www.biomedcentral.com//47I-2/48/7/233

(c) 2007 Naydenov et al; licensee BioMed Central Ltd.

This is an Open Access article distributed under the terms of the Creative Commons Attribution License (http://creativecommons.org/licenses/by/2.0), which permits unrestricted use, distribution, and reproduction in any medium, provided the original work is properly cited.

\begin{abstract}
Background: At the last glacial maximum, Fennoscandia was covered by an ice sheet while the tundra occupied most of the rest of northern Eurasia. More or less disjunct refugial populations of plants were dispersed in southern Europe, often trapped between mountain ranges and seas. Genetic and paleobotanical evidences indicate that these populations have contributed much to Holocene recolonization of more northern latitudes. Less supportive evidence has been found for the existence of glacial populations located closer to the ice margin. Scots pine (Pinus sylvestris $L$.) is a nordic conifer with a wide natural range covering much of Eurasia. Fractures in its extant genetic structure might be indicative of glacial vicariance and how different refugia contributed to the current distribution at the continental level. The population structure of Scots pine was investigated on much of its Eurasian natural range using maternally inherited mitochondrial DNA polymorphisms.
\end{abstract}

Results: A novel polymorphic region of the Scots pine mitochondrial genome has been identified, the intron I of nad7, with three variants caused by insertions-deletions. From 986 trees distributed among 54 populations, four distinct multi-locus mitochondrial haplotypes (mitotypes) were detected based on the three nad7 intron I haplotypes and two previously reported size variants for nadl intron $B / C$. Population differentiation was high $\left(G_{S T}=0.657\right)$ and the distribution of the mitotypes was geographically highly structured, suggesting at least four genetically distinct ancestral lineages. A cosmopolitan lineage was widely distributed in much of Europe throughout eastern Asia. A previously reported lineage limited to the lberian Peninsula was confirmed. A new geographically restricted lineage was found confined to Asia Minor. A new lineage was restricted to more northern latitudes in northeastern Europe and the Baltic region.

Conclusion: The contribution of the various ancestral lineages to the current distribution of Scots pine was asymmetric and extant endemism reflected the presence of large geographic barriers to migration. The results suggest a complex biogeographical history with glacial refugia shared with temperate plant species in southern European Peninsulas and Asia Minor, and a genetically distinct glacial population located more North. These results confirm recent observations for cold tolerant species about the possible existence of refugial populations at mid-northern latitudes contributing significantly to the recolonization of northern Europe. Thus, Eurasian populations of nordic plant species might not be as genetically homogenous as assumed by simply considering them as offsets of glacial populations located in southern peninsulas. As such, they might have evolved distinctive genetic adaptations during glacial vicariance, worth evaluating and considering for conservation. 


\section{Background}

The cold periods of the Pleistocene have had a dramatic impact on most organisms in temperate regions. Whereas the Artic ice sheet began to grow about 2.5 Myr ago, more severe climatic oscillations occurred mainly during the last 700000 year [1] with the consequence that the European biota has experienced repeatedly some drastic climate changes. Tree species responded through migration to regions where environmental conditions allowed them to survive $[2,3]$. Phylogeography investigates on the spatio-temporal dynamics of populations. It relies on inference from two main sources of information, i) macrofossils and pollen in sediment profiles, ii) population structure in DNA markers ideally inferred at the sequence level. Cytoplasmic markers, which are uniparently inherited in most plant species, are especially well suited for phylogeographic studies. They helped infer the number of genetically distinct ancestral lineages, their location during the last glacial maximum, and the postglacial migration routes for several tree and plant species in Europe [e.g. [4-11]]. These studies and others based on fossil evidence suggested that most plant and tree refuges were located in southern European peninsulas and the Balkans [12-15]. Glacial refugia and recolonization routes were found to coincide often for a number of plant and animal species [[3,16] and [17]]. In North America, common patterns are also starting to emerge and much knowledge has been rapidly gained from the analysis of species with wide distributions [e.g. [18-20]]. However, there is now increasing evidence that some European species were established much further north and east than previously assumed during glacial time [21-25]. Similar inferences have also been made in North America, where genetic and palynological evidence is accumulating for the presence of glacial populations much closer to the ice fronts as once thought [e.g. [26-29]]. Phylogeographic studies in Europe also indicate asymmetric contributions of glacial refugia to Holocene colonization: some ancestral lineages remained endemic, because of geographic barriers limiting migration, while others contributed considerably to the postglacial colonization of more northern latitudes $[[3,6,8]$ and $[30]]$.

Scots pine (Pinus sylvestris L., subgenus Diploxylon) is a long-lived evergreen monoecious forest tree species growing in a large variety of ecological conditions from western Europe to Asia. Of all pine species, it has the largest distribution [31,32]. Its natural range extends northwards from Spain to northern Fennoscandia, and westwards from longitudes $5^{\circ} \mathrm{W}$ in Spain and Scotland to $135^{\circ} \mathrm{E}$ in Siberia. While most of its natural range is contiguous, there are also large populations of Scots pine disconnected from the main natural range such as in Scotland, Spain, France, Turkey, and former Yugoslavia. Extensive variations in phenotypic traits as well as geographic races and types have been reported [33-37]. Much of this variation has been usually attributed to adaptation to edaphic and climatic factors [35,38]. Studies carried out over the last 30 years using isozymes, terpenes and flavonoid markers have also revealed the existence of distinct evolutionary units in Scots pine, which might be indicative of isolation in different glacial refugia. Although these studies were not entirely congruent and not aimed at deciphering effects related to glacial and postglacial history, they helped define biogeographical hypotheses for the western and northwestern European range of Scots pine [39-45]. Because of the regional scope of many of these studies and the different phenotypic or genetic attributes used, much biogeographical knowledge on the glacial and postglacial history of Eurasia remains to be gained from analysing the broad geographic distribution of Scots pine and by using homologous gene markers with stronger historical imprints.

In the Pinaceae, mtDNA is maternally inherited and dispersed through seeds only $[46,47]$. This mode of dispersion helps avoid the problems with inferring history from present-day distributions of nuclear or cpDNA markers because the latter are dispersed by both seeds and pollen in the Pinaceae, which produce a more rapid breakdown of the historical genetic signatures induced by glacial vicariance. However, one of the major difficulties one faces with plant mtDNA is the low level of variation in their exons and introns $[48,49]$, which limits the detection of variation between and within species at the sequence level [e.g. [47,50]]. An indel has been discovered in the intron $\mathrm{B} / \mathrm{C}$ of the mitochondrial gene nad1 in Scots pine, which allowed identifying a genetically distinct ancestral lineage in the Iberian Peninsula [6]. Restriction fragment length polymorphisms (RFLP) of a region encompassing the mitochondrial gene $\operatorname{cox} 1$ have also been found in populations of Scots pine from western Europe [5,51], which helped identifying two genetically distinct groups of populations each distributed on a large latitudinal range. The possibility for a refuge at northern latitudes was suggested in a previous study [5]. Given the little diversity observed in the mtDNA regions surveyed and the population sampling limited mostly to western Europe, it is likely that the pan-Eurasian Scots pine possesses more genetically distinct ancestral lineages. Such evidence would contribute towards a more complete understanding of the historical factors and processes leading to the current distribution of species genetic diversity throughout Eurasia.

In an effort to discern from a phylogeographic perspective the possible existence and contribution of mid-northern refugia to the glacial and postglacial history of Eurasian biota, we investigated the extant genetic structure of Scots pine with a set of populations covering much of the natu- 
ral range in Europe and also in Asia. We also report on a novel polymorphic mtDNA region in Scots pine, the intron 1 of the gene nad7, which is indicative of unknown genetically distinct maternal lineages. The location of one of these lineages in northern Europe supports the view that Quaternary refugia located outside European peninsulas at mid-northern latitudes might have played a significant role in the Holocene recolonization of Europe [22].

\section{Results}

\section{mtDNA polymorphisms and population differentiation}

Out of 15 mtDNA regions surveyed (Table 1), intraspecific polymorphism was detected for only two loci in Scots pine. Polymorphism was detected de novo for the intron 1 of nad 7 with three length variants. They were 1175,1170 and 1143 bp long and are hereafter called haplotypes A, $\mathrm{B}$, and $\mathrm{C}$, respectively. The size differences were caused by two single indels: one of 32 bp exclusive to haplotype $\mathrm{C}$ and one of $5 \mathrm{bp}$ exclusive to haplotype $\mathrm{B}$ (Table 2). As previously reported from a more limited sampling [6], two size variants were detected for the intron $\mathrm{B} / \mathrm{C}$ of nad1 among the 986 samples analysed herein. These fragments differed by a 31 bp indel and are hereafter called haplotypes A (217 bp) and B (248 bp). A third variant restricted to Italy was recently reported for this gene [30]. It was not detected in our sampled trees which were all from outside the Italian Peninsula. Primers for these two mtDNA regions were also tested on 100 to 500 individuals for each of five other pines of the subgenus Diploxylon (P. resinosa, P. mugo, P nigra, P. heldreichii, and P. contorta) and positive amplifications were obtained (data not shown).
The first four species belong to the section Pinus, but the first three are members of subsection Pinus (as for Scots pine) and Pinus heldreichii is member of subsection Pinaster. As for P. contorta, it belongs to section Trifoliae, subsection Contortae. Fragment length polymorphism was detected for both nad1 intron B/C and nad7 intron 1 in $P$. heldreichii. For $P$. nigra, only nad1 intron B/C showed polymorphism. No polymorphism was detected in $P$. mugo and $P$. resinosa. For $P$. contorta, polymorphism was only observed for nad7 intron 1 involving the same minisatellite-like marker as previously reported for this species and the closely related P. banksiana [20].

For Scots pine, the nomenclature used for mitochondrial multi-locus haplotypes (mitotypes) followed a two-letter code after the haplotypes observed for nad7 intron 1 (A, B, C) and nad1 intron B/C (A, B), respectively (Table 2). Among the four observed mitotypes, the most abundant one was AA (72.3\%), followed by BA (17.3\%), CA (5.8 $\%)$, and $\mathrm{AB}(4.6 \%)$ (Table 3$)$. The minimum spanning tree indicates that the mitotypes were more or less arranged as a star phylogeny with little sequence variation among them and no recombination (Figure 1B). The observed number of mitotypes per population $(n h)$ was 1 or 2 without exception, with an average of 1.50 (Table 3 ). The mitotype diversity index per population $(H)$ was low to moderate (average of 0.141 ) and ranged from 0 to 0.500 (Table 3). Population differentiation was high among the 54 populations, with $G_{\mathrm{ST}}$ and $N_{\mathrm{ST}}$ values of 0.657 and 0.685 , respectively (Table 4 ). When excluding the six more diverse populations from a presumed zone of

Table I: Mitochondrial regions tested'.

\begin{tabular}{|c|c|c|c|c|}
\hline Genomic region & $\begin{array}{c}\text { Annealing } \\
\text { temperature }\left({ }^{\circ} \mathrm{C}\right)\end{array}$ & PCR product size (bp) & Restriction enzymes tested & Primer source \\
\hline matR (intronl) & 58 & 550 & Sau3Al, Rsal, HindIII, Msel, Taql, BstUI & [47] \\
\hline mh05 & 59 & $1500^{4}$ & - & [91] \\
\hline$m h 09$ & 62 & 180 & - & [91] \\
\hline mh09' & 62 & $900^{4}$ & - & {$[91]$} \\
\hline$m h 33$ & 55 & 9004 & - & {$[91]$} \\
\hline$m h 35$ & 59 & Not amplified & - & {$[91]$} \\
\hline$m h 44$ & 59 & Not amplified & - & [91] \\
\hline nad I intron $B / C$, primers $H / / 2$ & 55 & $217-248$ & - & [6] \\
\hline nad3 intron I & 58 & 120 & - & [92] \\
\hline nad3-rps $/ 2$ (i.r.) ${ }^{3}$ & 58 & 360 & - & {$[92]$} \\
\hline nad5 intron I & 55 & 1100 & Sau3Al, Rsal, HindlII, Msel, Taql, BstUl, & {$[47]$} \\
\hline nad5 intron 4 & 59 & 900 & Sau3AI, Rsal, HindlII, Msel, Taql, BstUl, Tru9l & [93] \\
\hline nad7 intron I & 61 & 1200 & Sau3AI, Rsal, HindlII, Taql, BstUl, Tru9l & [47] \\
\hline SSU rRNA region $\mathrm{VI}$ & 62 & 400 & - & [94] \\
\hline SSU rRNA region $V 7$ & 50 & 250 & - & [94] \\
\hline
\end{tabular}

ITargeted regions, annealing temperatures, expected size of PCR products and restriction enzymes tested for primer pairs used to amplify I5 mtDNA regions of Scots pine.

${ }^{2}$ nadl intronB/C have been amplified (following Demesure et al [95] protocol) and tested with different restriction enzymes, only internal primers $\mathrm{H}$ and $\mathrm{I}$ of Soranzo et al [6] have shown polymorphism.

3Intergenic region.

4 Multiple fragments. 
Table 2: Mitochondrial DNA sequence polymorphisms detected in Scots pine'.

\begin{tabular}{|c|c|c|}
\hline Mitotype & nad7 intron I (positions 62I-68I) & nad I intron B/C (positions I0I-137) \\
\hline AA & $\begin{array}{l}\text { GGGATGCGTAAGCAGGCTCGACTGTTAAGGAGAGGGGCAAATAAGTAAAAA } \\
\text { AAAGGGCCTG }\end{array}$ & 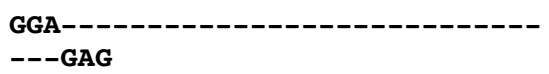 \\
\hline $\mathrm{BA}$ & $\begin{array}{l}\text { GGGATGCGTAAGCAGGCTCGACTGTTAAGGAGAGGGGCAAATAAGTAAAAA } \\
\text { AA----CTG }\end{array}$ & 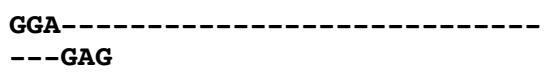 \\
\hline CA & $\begin{array}{l}\text { GGG-1 } \\
\text { GGCAAATAAGTAAAAAAAAGGGCCTG }\end{array}$ & 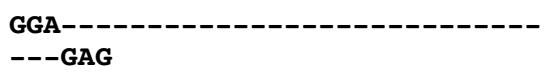 \\
\hline$A B$ & $\begin{array}{l}\text { GGGATGCGTAAGCAGGCTCGACTGTTAAGGAGAGGGGCAAATAAGTAAAAA } \\
\text { AAAGGGCCTG }\end{array}$ & $\begin{array}{l}\text { GGACCCTTTAGGGGGCTCGACCATAGGGAGA } \\
\text { GGAGAG }\end{array}$ \\
\hline
\end{tabular}

'Polymorphisms detected in the intron I of the mitochondrial gene nad7 and in the intron B/C of the mitochondrial gene nad In Scots pine, and nomenclature used for multi-locus haplotypes (mitotypes).

contact in central and northeastern Europe between two distinct mtDNA lineages (see below), the $G_{\mathrm{ST}}$ and $N_{\mathrm{ST}}$ values increased to 0.746 and 0.767 , respectively, among the remaining populations. However, the presence of a formal phylogeographic structure was not supported, as $N_{\mathrm{ST}}$ was not significantly higher than $G_{\mathrm{ST}}$. Lack of test power is likely the reason, given the small genetic divergence observed among the four mtDNA variants detected.

\section{Geographic structure}

The geographic distribution of mitotypes appeared to be essentially non-random, with clusters of mitotypes geographically quite well delineated (Figure 1A, see also SAMOVA test below). The Mediterranean region showed the highest diversity with three of the four mitotypes revealed in the study. The cosmopolitan haplotype AA was largely distributed and found in most of the populations sampled. Geographic structuring was evident for other mitotypes. Mitotype CA was present only in Asia Minor, in the Pontide Mountains of Turkey (populations $\# 14$ to \#16). Mitotype AB was found fixed in some high mountain populations of the Iberian Peninsula (Iberian cordillera - Zaragoza/Valencia provinces) (\#52 and \#54) and was observed as a rare variant in some populations of the Balkans (\#3, \#5,\#6,\#8 and \#10). The distribution of mitotype BA was quite unexpected: it was largely distributed in the lowland region of middle to northern latitudes in eastern Europe. It was prevalent in the Baltic region and quite frequent in Russia, west of the Ural Mountains. But it was also detected in Siberia (population \#44). A large zone composed of populations with variable mixed genetic background (mitotypes AA and BA) was observed in central and northeastern Europe. It includes most if not all populations bearing mitotype BA. The zone extends from the southeast of Russia to the Baltic States (see populations \#32, \#33, \#35, \#38, \#40, \#41, and \#43). The within-population mitotype diversity of these populations $(H=0.463)$ was much higher than elsewhere.

SAMOVA was conducted repeatedly by increasing the value of the number of population groups $(K)$ until the
$F_{\mathrm{CT}}$ value reached a maximum of 0.785 , which was obtained for $K=4$ (Table 4 ). For $K=3$, a maximum $F_{\mathrm{CT}}$ value of 0.720 was obtained. The four groups confirmed trends from visual inspection and corresponded to: (I) the majority of populations from Europe and Asia, (II) northeastern Europe, (III) Asia Minor and (IV) the high mountains of the Iberian Peninsula. Group I was the most widespread geographically, including 44 populations (Table 4). It contained mostly the cosmopolitan mitotype $\mathrm{AA}$ and, at a lower frequency, mitotype BA and AB. Differentiation among the populations of the group was moderate. Population differentiation within each of the three other groups (II, III, and IV) was smaller. Group II from northeastern Europe was largely dominated by mitotype BA. The two remaining groups III and IV were highly homogenous. Group III regrouped populations from Turkey fixed or nearly fixed for mitotype CA, and group IV regrouped populations from the Iberian Peninsula fixed for mitotype $A B$.

\section{Discussion mtDNA diversity and population differentiation}

DNA sequence variation is low in the mtDNA of conifers [e.g. $[47,50]]$. Accordingly, little intraspecific variation has been found in the mtDNA of $P$. sylvestris in western Europe, including four RFLP variants for the cox1 region [5] and three size variants at the locus nad1 intron B/C, of which two were found endemic to the Iberian and Italian Peninsulas $[6,30]$. The three new size variants reported herein for the locus nad7 intron 1 indicate new regionspecific variants for northeastern Europe and Asia Minor. No other length polymorphisms or substitutions were detected in Scots pine in spite of the screening of 15 distinct mtDNA regions. Highly informative minisatellitelike motifs such as those rarely detected in some spruce $[52,53]$ and pine taxa $[20]$ could not be detected in Scots pine.

The overall level of population differentiation estimated in this study from mitotype variation at the nad1 intron B/ $\mathrm{C}$ and nad7 intron 1 loci was rather high and similar to 
Table 3: Multi-locus haplotype frequencies and genetic diversity estimates in 54 natural populations of Scots pine.

\begin{tabular}{|c|c|c|c|c|c|c|c|c|c|c|c|c|}
\hline \multicolumn{2}{|c|}{ Population } & \multirow[t]{2}{*}{ Statel } & \multirow[t]{2}{*}{ Latitude $(\mathrm{N})$} & \multirow[t]{2}{*}{ Longitude $2(E / w)$} & \multirow[t]{2}{*}{ Altitude (m) } & \multirow[t]{2}{*}{ Sample size } & \multicolumn{4}{|c|}{ Mitotype counts ${ }^{3}$} & \multirow[t]{2}{*}{$n h^{4}$} & \multirow[t]{2}{*}{$H^{5}$} \\
\hline $\mathrm{Nb}$ & Name & & & & & & AA & $A B$ & BA & CA & & \\
\hline I & Bansko & BG & $41^{\circ} 48^{\prime}$ & $23^{\circ} 30^{\prime}$ & 1400 & 16 & 16 & - & - & - & I & 0 \\
\hline 2 & Borovo & BG & $41^{\circ} 30^{\prime}$ & $23^{\circ} 55^{\prime}$ & 1500 & 18 & 18 & - & - & - & 1 & 0 \\
\hline 3 & Chehliovo & BG & $41^{\circ} 53^{\prime}$ & $23^{\circ} 55^{\prime}$ & 1600 & 20 & 19 & - & - & - & 2 & 0.095 \\
\hline 4 & Chiroka Laka & BG & $4 I^{\circ} 4 I^{\prime}$ & $24^{\circ} 35^{\prime}$ & n.a. & 20 & 20 & - & - & - & 1 & 0 \\
\hline 5 & Dospat & BG & $41^{\circ} 40^{\prime}$ & $24^{\circ} 30^{\prime}$ & 1550 & 10 & 9 & 1 & - & - & 2 & 0.180 \\
\hline 6 & Laki & BG & $41^{\circ} 5 I^{\prime}$ & $24^{\circ} 50^{\prime}$ & 1400 & 20 & 18 & 2 & - & - & 2 & 0.180 \\
\hline 7 & Nevestino & BG & $42^{\circ} 06^{\prime}$ & $22^{\circ} 42^{\prime}$ & 1850 & 20 & 20 & - & - & - & 1 & 0 \\
\hline 8 & Pechtera & BG & $42^{\circ} 03^{\prime}$ & $24^{\circ} 22^{\prime}$ & 1400 & 20 & 19 & 1 & - & - & 2 & 0.095 \\
\hline 9 & Simitli & BG & $41^{\circ} 53^{\prime}$ & $23^{\circ} 10^{\prime}$ & n.a. & 20 & 20 & - & - & - & $\mathrm{I}$ & 0 \\
\hline 10 & Smolian & BG & $41^{\circ} 30^{\prime}$ & $25^{\circ} 20^{\prime}$ & 1400 & 20 & 18 & 2 & - & - & 2 & 0.180 \\
\hline 11 & Velingrad & BG & $42^{\circ} 05^{\prime}$ & $24^{\circ} 00^{\prime}$ & n.a. & 20 & 20 & - & - & - & 1 & 0 \\
\hline 12 & Grosser Priel & AT & $47^{\circ} 42^{\prime}$ & $14^{\circ} 17^{\prime}$ & 620 & 20 & 18 & - & 2 & - & 2 & 0.180 \\
\hline 13 & Merkenstein & AT & $48^{\circ} 59^{\prime}$ & $16^{\circ} 08^{\prime}$ & 550 & 19 & 19 & $\therefore$ & - & - & 1 & 0 \\
\hline 14 & Ilgaz Gakdake & $\mathrm{TR}$ & $41^{\circ} 02^{\prime}$ & $33^{\circ} 47^{\prime}$ & 1500 & 18 & - & - & - & 18 & 1 & 0 \\
\hline 15 & Eskipazan & $\mathrm{TR}$ & $40^{\circ} 53^{\prime}$ & $32^{\circ} 20^{\prime}$ & 1550 & 20 & - & - & - & 20 & 1 & 0 \\
\hline 16 & Ulupihar & TR & $40^{\circ} 53^{\prime}$ & $35^{\circ} 20^{\prime}$ & 1450 & 20 & 1 & - & - & 19 & 2 & 0.095 \\
\hline 17 & Zelenoborsk & $R U$ & $67^{\circ} 10^{\prime}$ & $32^{\circ} 21^{\prime}$ & n.a. & 17 & 4 & - & 13 & - & 2 & 0.360 \\
\hline 18 & Sosnovec & RU & $64^{\circ} 30^{\prime}$ & $34^{\circ} 45^{\prime}$ & n.a. & 20 & 3 & - & 17 & - & 2 & 0.255 \\
\hline 19 & Sucoozero & RU & $63^{\circ} 00^{\prime}$ & $32^{\circ} 21^{\prime}$ & n.a. & 20 & 3 & - & 17 & - & 2 & 0.255 \\
\hline 20 & Shala & RU & $61^{\circ} 47^{\prime}$ & $36^{\circ} 00^{\prime}$ & n.a. & 19 & 17 & - & 2 & - & 2 & 0.188 \\
\hline 21 & Sortovala & RU & $61^{\circ} 42^{\prime}$ & $30^{\circ} 4 I^{\prime}$ & n.a. & 15 & 7 & - & 8 & - & 2 & 0.498 \\
\hline 22 & Cugir seed orchard & RO & $45^{\circ} 52^{\prime}$ & $23^{\circ} 23^{\prime}$ & 230 & 14 & 14 & - & - & - & 1 & 0 \\
\hline 23 & Kurim Tisnov & $C Z$ & $49^{\circ} 30^{\circ}$ & $16^{\circ} 30^{\prime}$ & 400 & 12 & 7 & - & 5 & - & 2 & 0.486 \\
\hline 24 & Luzna Olesna & $C Z$ & $50^{\circ} 10^{\prime}$ & $13^{\circ} 70^{\prime}$ & 390 & II & 11 & - & - & - & 1 & 0 \\
\hline 25 & Murat & $\mathrm{FR}$ & $45^{\circ} 06^{\prime}$ & $2^{\circ} 15^{\prime}$ & n.a. & 9 & 9 & - & - & - & 1 & 0 \\
\hline 26 & Balnagowan Wood & UK & $57^{\circ} 16^{\prime}$ & $3^{\circ} 09^{\prime}$ & 240 & 14 & 14 & - & - & - & I & 0 \\
\hline 27 & Morayshire & UK & $57^{\circ} 33^{\prime}$ & $3^{\circ} 29^{\prime}$ & n.a. & 20 & 20 & - & - & - & 1 & 0 \\
\hline 28 & Hallestad District & SE & $58^{\circ} 46^{\prime}$ & $15^{\circ} 35^{\prime}$ & 85 & 13 & 11 & - & 2 & - & 2 & 0.260 \\
\hline 29 & Rumsulla District & SE & $57^{\circ} 4 I^{\prime}$ & $15^{\circ} 35^{\prime}$ & 150 & 20 & 15 & - & 5 & & 2 & 0.375 \\
\hline 30 & Kiuruvesi & $\mathrm{FI}$ & $63^{\circ} 40^{\prime}$ & $26^{\circ} 40^{\prime}$ & n.a. & 19 & I & - & 18 & - & 2 & 0.100 \\
\hline 31 & Vehkalahti & $\mathrm{FI}$ & $60^{\circ} 35^{\prime}$ & $27^{\circ} 20^{\prime}$ & n.a. & 20 & 1 & - & 19 & - & 2 & 0.095 \\
\hline 32 & Voronezh & RU & $50^{\circ} 30^{\prime}$ & $40^{\circ} 00^{\prime}$ & n.a. & 19 & 13 & - & 6 & - & 2 & 0.432 \\
\hline 33 & Orlovsk & RU & $52^{\circ} 30^{\prime}$ & $37^{\circ} 00^{\prime}$ & n.a. & 20 & 15 & - & 5 & - & 2 & 0.375 \\
\hline 34 & Kaunas & $\mathrm{LT}$ & $54^{\circ} 45^{\prime}$ & $24^{\circ} 05^{\prime}$ & 100 & 20 & 20 & - & - & - & 1 & 0 \\
\hline 35 & Riga & LV & $56^{\circ} 53^{\prime}$ & $24^{\circ} 08^{\prime}$ & n.a. & 20 & 11 & - & 9 & - & 2 & 0.495 \\
\hline 36 & Krasnoyarsk & RU & $60^{\circ} 00^{\prime}$ & $90^{\circ} 00^{\prime}$ & n.a. & 20 & 20 & - & - & - & 1 & 0 \\
\hline 37 & Spirinsk & RU & $54^{\circ} 00^{\prime}$ & $81^{\circ} 00^{\prime}$ & n.a. & 20 & 20 & - & - & - & 1 & 0 \\
\hline 38 & Vilnius & $\mathrm{LT}$ & $54^{\circ} 38^{\prime}$ & $25^{\circ} 28^{\prime}$ & 100 & 20 & 10 & - & 10 & - & 2 & 0.500 \\
\hline 39 & Krasnoe & RU & $54^{\circ} 00^{\prime}$ & $86^{\circ} 20^{\prime}$ & n.a. & 20 & 20 & - & - & - & 1 & 0 \\
\hline 40 & Rokiskis & $\mathrm{LT}$ & $55^{\circ} 48^{\prime}$ & $25^{\circ} 33^{\prime}$ & 120 & 20 & 8 & - & 12 & - & 2 & 0.480 \\
\hline 41 & Kaluzhkaya Ob. & RU & $54^{\circ} 00^{\prime}$ & $35^{\circ} 00^{\prime}$ & n.a. & 20 & 12 & - & 8 & - & 2 & 0.480 \\
\hline 42 & Tatarskaya Ob. & $R U$ & $55^{\circ} 00^{\prime}$ & $50^{\circ} 00^{\prime}$ & n.a. & 20 & 19 & - & 1 & - & 2 & 0.095 \\
\hline 43 & Dainava & LT & $53^{\circ} 55^{\prime}$ & $23^{\circ} 40^{\prime}$ & 80 & 20 & 12 & - & 8 & - & 2 & 0.480 \\
\hline 44 & Novosibirsk & RU & $55^{\circ} 05^{\prime}$ & $82^{\circ} 45^{\prime}$ & 200 & 20 & 16 & - & 4 & - & 2 & 0.320 \\
\hline 45 & Kievskaya Ob. & UA & $50^{\circ} 00^{\prime}$ & $30^{\circ} 00^{\prime}$ & n.a. & 20 & 20 & - & - & - & 1 & 0 \\
\hline 46 & Groenendaal & BY & $50^{\circ} 50^{\prime}$ & $42^{\circ} 10^{\prime}$ & n.a. & 18 & 18 & - & - & - & 1 & 0 \\
\hline 47 & Baiyinna-Heilongjiang & $\mathrm{CN}$ & $52^{\circ} 21^{\prime}$ & $125^{\circ} 40^{\prime}$ & n.a. & 17 & 17 & - & - & - & 1 & 0 \\
\hline 48 & Jilin Prov. & $\mathrm{CN}$ & $43^{\circ} 00^{\prime}$ & $126^{\circ} 00^{\prime}$ & n.a. & 17 & 17 & - & - & - & 1 & 0 \\
\hline 49 & Sung-Hua-Chiang & $\mathrm{CN}$ & $46^{\circ} 00^{\prime}$ & $127^{\circ} 00^{\prime}$ & 700 & 17 & 17 & - & - & - & 1 & 0 \\
\hline 50 & Heilongjiang Prov. & $\mathrm{CN}$ & $47^{\circ} 00^{\prime}$ & $127^{\circ} 00^{\prime}$ & n.a. & 20 & 20 & - & - & - & 1 & 0 \\
\hline 51 & Sierras Penibeticas & ES & $37^{\circ} 20^{\prime}$ & $2^{\circ} 50^{\prime} w$ & 2000 & 18 & 18 & - & - & - & 1 & 0 \\
\hline 52 & Montes Universales & ES & $40^{\circ} 20^{\prime}$ & $1^{\circ} 50^{\prime} w$ & 1700 & 19 & - & 19 & - & - & I & 0 \\
\hline 53 & Guadarrama & ES & $40^{\circ} 45^{\prime}$ & $4^{\circ} 05^{\prime} w$ & 1900 & 19 & 18 & 1 & - & - & 2 & 0.100 \\
\hline 54 & Alto Tago & ES & $40^{\circ} 44^{\prime}$ & $2^{\circ} 10^{\prime} w$ & 1500 & 18 & - & 18 & - & - & 1 & 0 \\
\hline \multicolumn{2}{|c|}{ Total } & & & & & 986 & 713 & 45 & $17 \mid$ & 57 & - & - \\
\hline \multicolumn{2}{|c|}{ Average } & & & & & 18.3 & - & - & - & - & 1.50 & 0.141 \\
\hline
\end{tabular}

'AT, Austria; BG, Bulgaria; BY, Belarus; CN, China; CZ, Czech Republic; ES, Spain; FI, Finland; FR, France; LT, Lithuania; LV, Latvia; RO, Romania; RU, Russian Federation; SE, Sweden; TR, Turkey; UA, Ukraine; UK, United Kingdom.

${ }^{2}$ The " $w$ " indicates the longitude west of Greenwich meridian.

${ }^{3}$ The first letter of multi-locus haplotype (mitotype) refers to the haplotype observed at locus nad7 intronl and the second letter refers to the haplotype observed at locus nad I intron B/C following nomenclature in Table 2.

${ }^{4}$ Number of distinct mitotypes per population.

5Mitotype diversity. 
Table 4: Genetic diversity parameters and population differentiation estimates'.

\begin{tabular}{|c|c|c|c|c|c|c|c|c|c|}
\hline Group & Populations & Region (Country) & $N^{2}$ & $h h^{3}$ & $A^{4}$ & $H^{5}$ & $G_{S T}{ }^{6}$ & $\mathrm{~N}_{\mathrm{ST}}{ }^{7}$ & $F_{\mathrm{CT}^{8}}{ }^{8}$ \\
\hline I & $\begin{array}{l}I, 2,3,4,5,6,7,8,9,10,11,12,13,20 \\
21,22,23,24,25,26,27,28,29,32,33 \\
34,35,36,37,38,39,40,41,42,43,44, \\
45,46,47,48,49,50,51,53\end{array}$ & Most populations from Europe and Asia & 795 & 3 & 1.48 & 0.147 & 0.262 & 0.270 & 0.785 \\
\hline II & $17,18,19,30,31$ & Karelia and NE Scandinavia (Russia/Finland) & 96 & 2 & 2.0 & 0.213 & 0.001 & 0.001 & \\
\hline III & $14,15,16$ & Middle East (Turkey) & 58 & 2 & 1.33 & 0.032 & 0 & 0 & \\
\hline IV & 52,54 & Iberian Peninsula (Spain) & 37 & 1 & 1.0 & 0 & n.a. & n.a. & \\
\hline Total & & & 986 & 4 & 1.50 & 0.141 & 0.657 & 0.685 & \\
\hline
\end{tabular}

'Estimates for groups of populations of Scots pine delineated by SAMOVA and maximizing geographic structure.

2Sample size.

${ }^{3}$ Number of distinct multi-locus haplotypes (mitotypes) observed in each group.

${ }^{4}$ Average number of mitotypes per population in each group.

${ }^{5}$ Average mitotype diversity per population in each group.

${ }^{6}$ Differentiation among populations in each group.

${ }^{7}$ Fixation index using PERMUT software [88].

${ }^{8}$ Differentiation among the four groups.

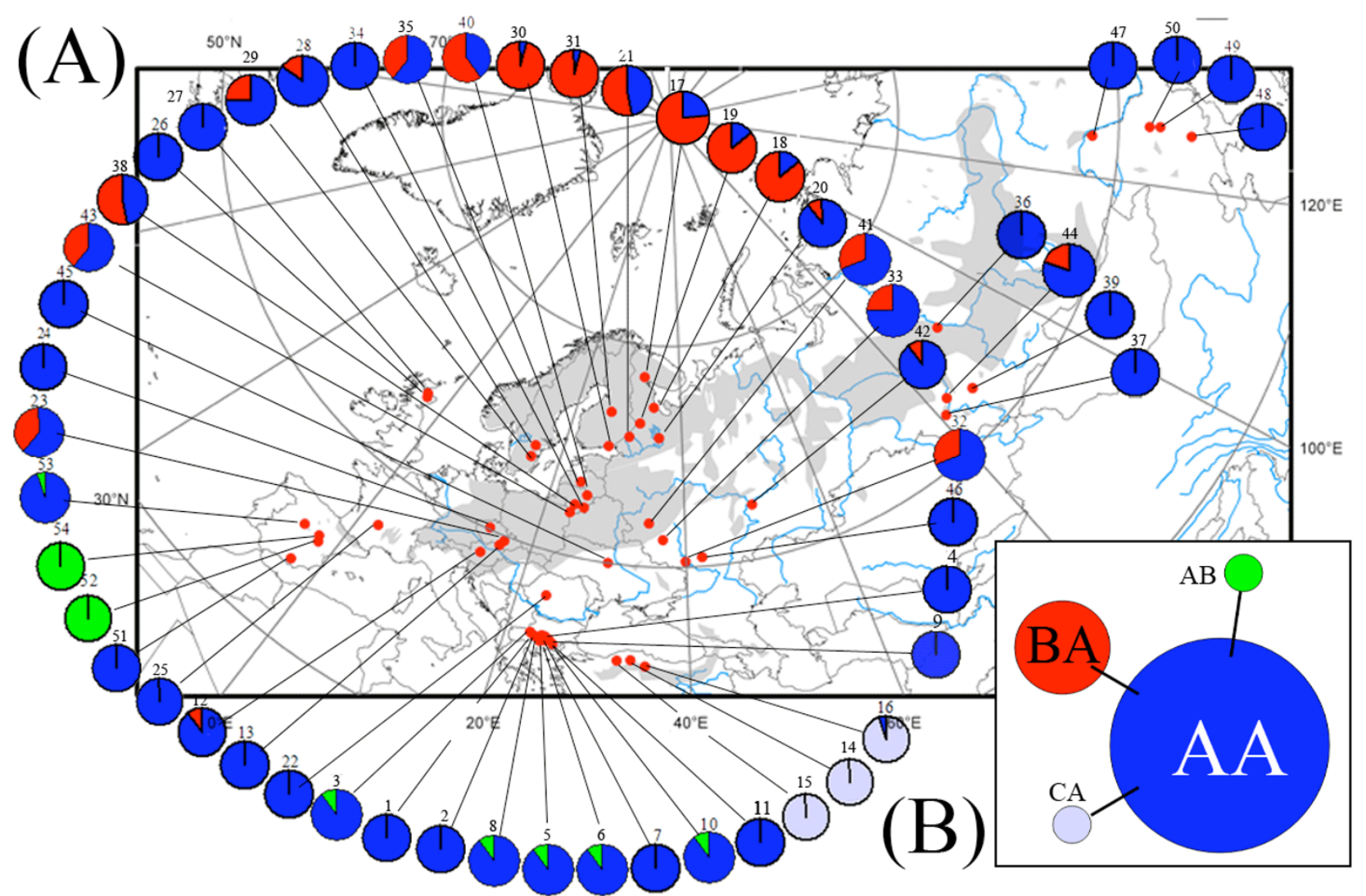

Figure I

Geographic distribution of multi-locus mtDNA haplotypes (mitotypes) in Scots pine natural populations from Europe and Asia. (A) Gray color represents the natural range of Scots pine. The colours corresponding to the mitotypes are defined in plate B. Note a large mixed zone involving the ancestral lineages AA and BA over northeastern Europe. (B) Haplotype network of the four mitotypes identified in this study. Each link represents one indel. The size of circles is proportional to the relative frequency of mitotypes (for exact frequencies, see Table 3). 
that reported in earlier studies restricted to Scots pine populations from western Europe based on RFLPs of the cox1 region $\left(G_{\mathrm{ST}}=0.83\right.$; $\left.[5]\right)$ or indels of the nad1 intron $\mathrm{B} / \mathrm{C}$ $\left(G_{S T}=0.60 ;[6]\right)$. Such estimates are in line with averages reported for maternally inherited markers for a number of conifer and angiosperm taxa [54]. The amount of population differentiation determined by nuclear markers such as isozymes was generally much smaller in Scots pine with $G_{S T}$ values ranging between 0.025 and 0.076 [43,55-61]]. However, these studies were carried out mostly at the regional level. Among-population differentiation was also much higher for mtDNA markers than for paternally inherited cpDNA markers in a Scots pine study covering much of the species range $\left(G_{\mathrm{ST}}=0.11 ;[62]\right)$, as usually observed in other conifers [e.g. [54,63]].

\section{Geographic structure}

The present study confirms the existence of a genetically distinct set of populations in the high mountains of the Iberian Peninsula $[5,6]$ while variants discovered in the intron 1 of nad7 signal distinctive evolution in Asia Minor and northeastern Europe. Haplotype B at locus nad1 intron $\mathrm{B} / \mathrm{C}$ was observed mostly in the Iberian Peninsula in some high elevation populations of the Zaragoza/ Valencia regions where it was fixed or nearly fixed. It was observed only sparingly west of Catalonia. Such a distribution indicates that these Catalan populations have been isolated during glaciations and have not contributed to the recolonization of Europe [[5,6] and [30]]. A distinct dynamics of Catalan populations from the rest of the Iberian Peninsula has also been reported for other species like Aleppo pine [64], Maritime pine [9,65], and white oaks [8]. In the present study, haplotype B of nad1 intron $\mathrm{B} / \mathrm{C}$ has also been discovered, albeit at low frequency, in five other populations located in Bulgaria, in the Balkan Peninsula, thus far away from the center of prevalence for this haplotype in the Iberian Peninsula. Long-distance seed dispersal could be invoked but is unlikely over such long distances, given the heterogenous topography and relative isolation of Iberia. The probability of such longdistance movements would be higher in the northern and more eastern parts of Scots pine natural range, given the lack of major physical barriers. Another perhaps more plausible explanation for the rare presence of haplotype $\mathrm{B}$ of nad1 intron B/C in some Balkan populations could be that it is ancient and was present in more than one southern ice refugia. Its high or low frequency, depending on the region considered, could be attributable to stochastic variation, especially if southern refugia populations suffered from severe bottlenecks. The weak occurrence of this haplotype in the Balkans might also result from human activity, as previously suggested for the rare presence of this variant in Poland [6]. Whereas the hypothesis of seed source transfer cannot be totally ruled out, it is difficult to sustain because of (i) the lack of hard evidence for such seed source transfer between the Balkans and the Iberian Peninsula in the past; (ii) natural stands in which seeds were collected existed long before forest management activities began in Europe; and (iii) the relative conservatism of forest seed transfer guidelines in the Balkan region [66]. A third explanation could relate to ancient mtDNA capture from hybridizing species in the region $[67,68]$. Accordingly, phylogeographical studies of other pine species in the region using the same gene locus might help clarify the issue.

The detection and high prevalence of haplotype $\mathrm{C}$ of nad7 intron 1 in Asia Minor populations only is a strong signal for the presence of a genetically distinct glacial population. This relictual population would have experienced severe bottlenecks, because populations were all fixed for this haplotype except for one tree harbouring the cosmopolitan haplotype A. After glaciation, it would have remained isolated, eastward by the Caucasus Mountains, northward by the Black Sea, and westward by the Bosphorus passage. The cold and arid climate in this region during the Holocene might have also impeded the expansion of this population [69], but not its survival as Scots pine can survive under very harsh conditions [70].

The high prevalence of haplotype B of nad7 intron 1 in northeastern Europe suggests the presence of a genetically distinct glacial population at more northern latitudes than previously thought, an idea that had already been suggested for Scots pine [5]. A recent mutation during the Holocene giving rise to haplotype B of nad7 intron 1 is unlikely, given the widespread distribution of this haplotype. As well, homoplasy is unlikely, given the low rate of variation of angiosperm and conifer mitochondrial introns $[47,49]$. A large number of populations had mixed composition of both haplotypes A and B of nad7 intron 1 in central and northeastern Europe. Their diversity index was highest among all populations surveyed, which could result for the meeting of two genetically distinct glacial lineages (A and B), or indicates that the glacial population harboring haplotype B had mixed genetic composition. The uneven distribution of haplotype B of nad7 intron 1 among these populations, with a higher prevalence of haplotype $B$ as one moves northward, could result from successive founder events during colonization [71], as recently proposed for European hedgehogs [72]. This is likely, given than that migration from more southern latitudes was necessary to colonize these previously glaciated areas.

\section{Implications for glacial and postglacial history of European vegetation}

There is some evidence from fossil and palynological data that cold adapted tree species occupied mid-altitude sites in the mountains of southern Europe during the last gla- 
cial stage [13]. Moreover, the southern peninsulas of Iberia, Italy, the Balkans, and Greece, which are separated from the rest of Europe by major mountain ranges such as the Pyrenees, Alps and Caucasus, were identified as major glacial refugia for many species [[14,30] and [65]]. Our genetic data indicates that a genetically distinct glacial refuge existed in Asia Minor as well. Tree pollen, including that of the genus Pinus, was recorded in the Balkans about 14000 years BP [13] while it was barely present as late as 10500 years BP in southwestern Turkey where the climate was cold and dry with steppe vegetation [69]. Pine pollen attained its maximum only in early Holocene in western Anatolia and in mid-Holocene in more eastern areas, likely because of similar climatic limitations $[73,74]$. Thus, it is apparent that tree populations would have been scarce in the region at LGM, $21 \mathrm{Kyr}$ ago. The refuge is also unlikely to have contributed much to the postglacial colonization of Europe, given the genetic discontinuity detected in Scots pine. The peculiar location of Turkey between the Black and Mediterranean seas would have promoted isolation from more northern areas. It is likely that other elements of the steppe vegetation in the region also represent relicts from the pre-Holocene era and suffered similar effects during glacial periods, as shown recently for field mouse [75]. As such, it is expected that they would show a distinct genetic background, as that detected in Scots pine.

The exact location and size of the Scots pine glacial population giving rise to the large spread of haplotype $\mathrm{B}$ of nad7 intron 1 in eastern or northeastern Europe remain unknown. Based on fossil data, Scots pine glacial populations existed in the Balkans and possibly even in central Europe [Litynska-Zajac M. cited by Stewart and Lister $[22,23]]$. The large spread of haplotype A of nad7 intron 1 throughout Europe is likely the consequence of an expansion from glacial populations from that region [30]. Such spread northwestwards towards Germany and France and northeastwards throughout Eastern Europe and Siberia correlates geographic dispersion patterns and colonization routes inferred for a grasshopper [76], for European beech [77], for the oaks [4], and for Norway spruce $[52,78]$. However, some of these colonization routes are still open to alternative interpretation. Furthermore, such observations do not correlate well with the exceptionally northern location of haplotype B of nad7 intron 1.

The peculiar northern distribution of haplotype B of nad7 intron 1 indicates that Scots pine has likely survived in a refuge distinct from those usually recognized in the southern peninsulas of Europe, perhaps under the form of scattered glacial populations spread over sizeable latitudinal areas reaching European mid-latitudes not far from the ice front. Scots pine is known to survive and grow reasonably well upon permafrost [72]. Evidence is also accumulating regarding the existence of glacial populations located at more northern latitudes [e.g. [25,28] and [29]] and their significant contribution to Holocene colonization $[22,25]$. In addition, if the mixed zone observed in northcentral and northeastern Europe between the cosmopolitan AA mitotype and the northern BA mitotype represents truly a zone of secondary contact, the northern location and shape of this zone would not correspond well to the meeting of two ancestral lineages both located in or near southern European peninsulas. While the existence of such zones with typically higher genetic diversity has been reported for other tree species in Europe [[3,4] and [16]] as well as in North America $[19,20]$ where ancestral lineages from southern latitudes would converge at more northern latitudes, this possible zone of contact would more likely correspond to the junction between a lineage moving northwards from the Balkans or from even more east (the AA lineage), and a lineage of more northern or northeastern origin (the BA lineage). In one rare occurrence of similar observation, Taberlet et al [3] recognized a contact zone of migration fronts as far north as in Scandinavia for Picea abies. They proposed that the area was presumably colonized from the south and from the northeast by populations originating from different refugia.

While the current areas of maximum abundance of haplotype B of nad7 intron1, Finland and northwestern Russia, were completely glaciated at LGM [79], it is likely that trees colonizing the region would have migrated northward from a region anywhere west of the Ural Mountains. There are indications from general circulation models that the climate during the last glacial maximum was warm enough to allow Scots pine to survive well as far north as above $50^{\circ} \mathrm{N}$ in isolated regions of northern Ukraine and southwestern Russia, for instance [30]. A location more south is also possible if founder events after long-distance dispersal are hypothetized, followed by drift and lineage sorting to account for the high abundance of haplotype $B$ of nad7 intron 1 as one moves into Finland and northwestern Russia. However, this hypothesis becomes unlikely for long-distance dispersal from refuges located in the southern European peninsulas, given the absence of haplotype B of nad7 intron 1 in southern populations of Scots pine.

More mtDNA polymorphisms will need to be discovered in order to distinguish Scots pine disjunct populations from eastern Europe and Asia and investigate if significant glacial vicariance factors existed in this vast region. Siberian populations where the cosmopolitan mitotype AA was dominant might have been established from a glacial population located in southwestern Siberia, in the upper Irtysh River Valley [80-82], or from a more southern location. As for Scots pine populations located in the far-east in China where the cosmopolitan mitotype AA was found 
fixed, it is not clear if it is derived from a more western refuge located in southwestern Siberia (see above) or if a refuge existed in northeastern China. Palynological evidence suggests that pine was present at several locations in the region during the last glaciation, but it is unclear if the fossil pollen was representative of Scots pine as many pine species are endemic to the region [82].

\section{Conclusion}

The present study suggests a more complex biogeographical history than previously thought for Scots pine and presumably, for its associated plant congeners. The study is congruent with others $[[3,15,17]$ and [21]] about the asymetry of glacial refugia in contributing to the postglacial recolonization of Eurasia. This trend is best exemplified by the prevalent nad7 intron 1 haplotype found specific to the relictual population from Turkey and from nowhere else in Eurasia. It indicates that Asia Minor is likely to represent a prime area of endemism supporting genetically distinct lineages unlikely to be found in the rest of Eurasia. Such a trend highlights the geography of the region as an important vicariance factor limiting migration and gene flow. Similarly as for other areas of endemism in Europe (e.g. Iberian and Italian Peninsulas), seed source movements from the rest of Eurasia to Asia Minor should be restricted. Reserves could be considered to ensure in situ preservation of relictual genetic diversity and structure, which need to be further documented at the level of the chloroplast and nuclear genomes as well as for other plant and animal species.

The discovery of a genetically distinct North-European lineage suggests that some glacial populations may have survived isolated from refugia in South European peninsulas at more mid- northern latitudes. Given the colonization time lag for southern populations to reach northern latitudes due to distance, topographic barriers $[2,83]$ and competition from a possible network of resident populations sparingly distributed, such genetically distinct glacial populations have apparently played a major role in the postglacial colonization of parts of northern Europe. A likely consequence of such glacial vicariance is that extant northern populations of nordic plant species might not be as homogenous as assumed by simply considering them as offsets of glacial populations located at southern latitudes. This observation implies that they might have evolved distinctive genetic adaptations during glacial vicariance, worth evaluating and considering in conservation programs $[84,85]$. As well, the extensive mixing of two ancestral lineages in central and northeastern Europe provides the opportunity to perhaps identify and preserve unique adaptive diversity.

\section{Methods \\ Population sampling and DNA isolation}

Fifty-four natural populations were sampled and their location was chosen in order to represent most of the natural range of the species in Europe and Asia. Twenty populations were from the eastern part of the Ural Mountains and Asia (Russia and China) as well as from Asia Minor (Turkey), and the remaining 34 populations from 13 European countries (Figure 1 and Table 3). Each seed lot represented a bulk of seeds from a minimum of 50 individuals with a minimum distance of $100 \mathrm{~m}$ between them. Seed samples were collected from each population and stored in darkness at $4{ }^{\circ} \mathrm{C}$ until they were processed.

Seeds from each population were soaked on moistened filter paper in Petri dishes at $26^{\circ} \mathrm{C}$ under a photoperiod of 14 hours for 2 days until DNA extraction. DNA was extracted from the haploid megagametophyte for each of 9 to 20 seeds per population using a genomic DNA mini preparation kit (Sigma-Aldrich), for a total of 986 DNA samples and an average of 18.3 samples per population (Table 3). A screening for mtDNA polymorphism was conducted by assembling an exploratory panel of 26 out of the 986 DNA samples, each representative of a different population and ensuring that geographically widespread populations were represented.

\section{Screening for mtDNA polymorphism and sequencing}

A total of $15 \mathrm{mtDNA}$ regions were screened for polymorphisms using various techniques (Table 1). Polymorphism was detected for only two regions, nad1 intron B/C (2 haplotypes), and nad7 intron 1 (3 haplotypes). DNA samples bearing different haplotypes for each of the variable mitochondrial regions were selected (3 DNA samples per locus and per haplotype from different populations) and sequenced in order to determine the exact nature of every fragment length polymorphism and to detect the presence of potential fragment length homoplasies. Direct sequencing of the two DNA strands was carried out on an automated 3730XL DNA analyser (Applied Biosystems) with the dideoxynucleotide chain termination procedure using the appropriate amplification primers and Big Dye Terminator kit-V.3.1 (Applied Biosystems). The complete sequences for nad7 intron 1 haplotypes have been deposited in GenBank (GenBank: DQ665913 to DQ665915). The complete sequence for nad1 intron B/C was already available in GenBank [6]. Multi-locus mtDNA haplotypes (mitotypes) were then defined by considering single-locus mtDNA genotypes simultaneously and their relationships were determined by statistical parsimony analysis of the aligned sequences using the program TCS [86].

\section{mtDNA population survey and numerical analyses}

Single-locus haplotypes were determined for each of 986 individuals with the internal primers pair $n a d 1 \mathrm{H}$ and 
nad1I for nad1 intron B/C, as described by Soranzo et al [6], and the primers nad7 intron1 forward and nad7 intron 1 reverse for nad7 intron 1, as described by Jaramillo-Correa et al [19]. Primers were synthetized by Invitrogen. DNA was amplified in a PTC225 thermal cycler (MJ Research) using Platinum Taq DNA Polymerase (Invitrogen) in a $12 \mu \mathrm{l}$ reaction volume, following protocols published by Soranzo et al [6] for nad1 intron B/C and Jaramillo-Correa et al [19] for nad7 intron 1. PCR products of nad 7 intron 1 were digested with the restriction enzyme Sau3A I (Promega) and then separated through $8 \%$ non denaturating polyacrylamide gels (in TBE) in order to detect putative cleaved amplified polymorphic sites (CAPS). PCR products of nad1 intron B/C were electrophoresed through $2 \%$ agarose gel.

The number of observed mitotypes per population $(n h)$ and the total mtDNA diversity per population ( $H$; equivalent to the expected heterozygosity, $H_{\mathrm{E}}$, for diploid data; [87]) were estimated. Population differentiation was estimated using two fixation indices, $G_{\mathrm{ST}}$ and $N_{\mathrm{ST}}$, using PERMUT [88]. The first statistics is calculated based solely on mitotype frequencies, whereas the second one takes into account the genetic relatedness among mitotypes. Thus, if the estimated $N_{\mathrm{ST}}$ value is higher than the $G_{\mathrm{ST}}$ value, it indicates that closely related mitotypes tend to cluster in the same area, supporting the presence of a formal phylogeographic structure.

Geographic population structure was assessed using a spatial analysis of molecular variance SAMOVA $1.0[89,90]$. A matrix of pairwise distances between populations was first constructed using mitotype frequencies, as well as a matrix of pairwise geographic distances between populations. The method implemented in SAMOVA employs a simulated annealing procedure and uses allele frequency data along with geographic coordinates of the sampled populations to identify population groups maximizing genetic differentiation. We determined the most likely number of $K$ groups by repeatedly running SAMOVA with variable numbers of groups and by choosing the number resulting in a maximum $F_{\mathrm{CT}}$ value [90]. The configuration with the largest $F_{\mathrm{CT}}$ value among the 100 tested was retained as the best grouping of populations.

\section{Authors' contributions}

$\mathrm{KN}$ was responsible for study design and sampling collection, preparing DNA samples and participated in data analysis and manuscript writing. SS was responsible for PCR assays and DNA sequencing, and participated in data analysis and manuscript writing. JBe was responsible for marker discovery, participated in data analysis, manuscript writing and co-funding of the study. FT contributed to manuscrit review and to co-funding of the study. JBo participated in scaling PCR assays, data analysis, manu- script writing, and co-funding of the study. All authors read and approved the final manuscript.

\section{Acknowledgements}

We are grateful to A. Alexandrov (Forest Research Institute, Bulgarian Academy of Sciences), A. Esqudero (ESCET, Universidad Rey Juan Carlos, Spain), B. Raevsky (Forest research Institute of the Karelian Research Center), C. Baldwin (Northern Forest Research Station, Roslin, Midlothian, UK) and M. Topack (Ministry of Forestry, Turkey) for providing seed collections. We also thank I. Naydenova (Univ. du Québec Abitibi-Témiscamingue) for help with DNA isolation, M. Deslauriers and E. Pouliot (Canadian Forest Service) for help in designing the new markers reported in this study, and J. Godbout and J.P. Jaramillo-Correa (Univ. Laval) for assistance with analyses. We also acknowledge constructive comments made by the reviewers, which particularly helped improve the discussion. This research was financially supported by grants to F. Tremblay from the Natural Sciences and Engineering Research Council of Canada (NSERC), to J. Beaulieu from the Canadian Forest Service, and to J. Bousquet from NSERC and the Canada Research Chair in Forest and Environmental Genomics.

\section{References}

I. Webb T, Bartlein P]: Global changes during the last $\mathbf{3}$ million years: climatic controls and biotic responses. Annu Rev Ecol Syst 1992, 23:141-173.

2. Hewitt GM: Some genetic consequences of ice ages, and their role in divergence and speciation. Biol J Linn Soc Lond 1996, 58:247-276.

3. Taberlet P, Fumagalli L, Wust-Saucy AG, Cosson JF: Comparative phylogeography and postglacial colonization routes in Europe. Mol Ecol 1998, 7:453-464.

4. Dumolin-Lapègue $S$, Demesure $B$, Fineschi $S$, Le Corre $V$, Petit RJ: Phylogeographic structure of white oaks throughout the European continent. Genetics 1997, | 46: |475-|487.

5. Sinclair WT, Morman JD, Ennos RA: The postglacial history of Scots pine (Pinus sylvestris L.) in western Europe: evidence from mitochondrial DNA variation. Mol Ecol 1999, 8:83-88.

6. Soranzo N, Alia R, Provan J, Powell W: Patterns of variation at a mitochondrial sequence-tagged-site locus provides new insights into the postglacial history of European Pinus sylvestris populations. Mol Ecol 2000, 9:1205-121I.

7. Gugerli F, Sperisen C, Büchler U, Magni F, Geburek T, Jeandroz S, Senn J: Haplotype variation in a mitochondrial tandem repeat of Norway spruce (Picea abies) populations suggests a serious founder effect during postglacial re-colonization of the western Alps. Mol Ecol 200I, I 0: I 255-1263.

8. Petit RJ, Brewer S, Bordács S, Burg K, Cheddadi R, Coart E, Cottrell J, Csaikl UM, van Dam B, Deans JD, Espinel S, Fineschi S, Finkeldey R, Glaz I, Goicoechea PG, Jensen JS, König AO, Lowe AJ, Madsen SF, Mátyás G, Munro RC, Popescu F, Slade D, Tabbener H, de Vries SGM, Ziegenhagen B, de Beaulieu JL, Kremer A: Identification of refugia and post-glacial colonisation routes of European white oaks based on chloroplast DNA and fossil pollen evidence. For Ecol Manage 2002, I56:49-74.

9. Burban C, Petit RJ: Phylogeography of maritime pine inferred with organelle markers having constrasted inheritance. Mol Ecol 2003, I 2: | 487- | 495

10. Palmé AE, Su Q, Rautenberg A, Manni F, Lascoux M: Postglacial recolonization and cPDNA variation in silver birch, Betula pendula. Mol Ecol 2003, I 2:20I-2I 2 .

II. Heuertz M, Fineschi S, Anzidei M, Pastorelli R, Salvini D, Paule L, Frascaria-Lacoste N, Hardy OJ, Vekemans X, Vendramin GG: Chloroplast DNA variation and postglacial recolonization of common ash (Fraxinus excelsior L.) in Europe. Mol Ecol 2004, 13:3437-3452.

12. Huntley B, Birks HJB: An Atlas of Past and Present Pollen Maps for Europe: 0-13000 years Ago Cambridge (UK): Cambridge University Press; 1983.

13. Bennett KD, Tzedakis PC, Willis KJ: Quaternary refugia of north European trees. J Biogeogr 1991, 18:103-115. 
14. Willis KJ: The vegetational history of the Balkans. Quaternary Sci Rev 1994, 13:769-788.

15. Brewer S, Cheddadi R, de Beaulieu JL, Reille M, Data contributors: The spread of deciduous Quercus throughout Europe since the last glacial period. For Ecol Manage 2002, I56:27-48.

16. Petit RJ, Aguinagalde I, de Beaulieu JL, Bittkau C, Brewer S, Cheddadi R, Ennos R, Fineschi S, Grivet D, Lascoux M, Mohanty A, MüllerStarck G, Demesure-Musch B, Palmé A, Martin JP, Rendell S, Vendramin GG: Glacial refugia: hotspots but not melting pots of genetic diversity. Science 2003, 300:1563-1565.

17. Emerson BC, Hewitt GM: Phylogeography. Curr Biol 2005, I5:R367-R37|.

18. Tremblay NO, Schoen DJ: Molecular phylogeography of Dryas integrifolia: glacial refugia and postglacial recolonization. Mol Ecol 1999, 8: II87-1198.

19. Jaramillo-Correa JP, Beaulieu J, Bousquet J: Variation in mitochondrial DNA reveals multiple distant glacial refugia in black spruce (Picea mariana), a transcontinental North American conifer. Mol Ecol 2004, 13:2735-2747.

20. Godbout J, Jaramillo-Correa JP, Beaulieu J, Bousquet J: A mitochondrial DNA minisatellite reveals the postglacial history of jack pine (Pinus banksiana), a broad-range North American conifer. Mol Ecol 2005, | 4:3497-35I2.

21. Hewitt GM: Post-glacial re-colonization of European biota. Biol J Linn Soc Lond 1999, 68:87-II 2

22. Stewart JR, Lister AM: Cryptic northern refugia and the origins of the modern biota. Trends Ecol Evol 200I, 16:608-613.

23. Taberlet $P$, Cheddadi R: Quaternary refugia and persistence of biodiversity. Science 2002, 297:2009-20I0.

24. Willis KJ, van Andel TH: Trees or no trees? The Environments of central and eastern Europe during the last glaciation. Quaternary Sci Rev 2004, 23:2369-2387.

25. Magri D, Vendramin GG, Comps B, Dupanloup I, Geburek T, Gömöry D, Latalowa M, Litt T, Paule L, Roure JM, Tantau I, van der Knaap WO, Petit RJ, de Beaulieu JL: A new scenario for the Quaternary history of European beech populations : palaeobotanical evidence and genetic consequences. New Phytol 2006, I7I:199-22I.

26. Baker RG: Pollen sequence from the late Quaternary sediments in Yellowstone Park. Science 1970, 168:1449-1450.

27. Mehringer PJ Jr, Arno SF, Petersen KL: Postglacial history of lost trail pass bog, Bitteroot Mountains, Montana. Arct Antarc Alp Res 1977, 9:345-368.

28. Rowe KC, Heske EJ, Brown PK, Paige KN: Surviving the ice: Northern refugia and postglacial colonization. Proc Natl Acad Sci USA 2004, I0I: 10355-10359.

29. Anderson LL, Hu FS, Nelson DM, Petit RJ, Paige KN: Ice-age endurance: DNA evidence of a white spruce refugium in Alaska. Proc Natl Acad Sci USA 2006, I03: 12447- 12450.

30. Cheddadi R, Vendramin GG, Litt T, François L, Kageyama M, Lorentz S, Laurent JM, de Beaulieu JL, Sadori L, Jost A, Lunt D: Imprints of glacial refugia in the modern genetic diversity of Pinus sylvestris. Glob Ecol Biogeogr 2006, I 5:27|-282.

31. Farjon A: Pines. Drawings and descriptions of the genus Pinus Leiden: Brill and Backhuys Publishers; 1984.

32. Vidakovic M: Conifers : morphology and variation Zagreb: Graficki Zavod Hrvatske; 1991.

33. Svoboda P: Forest trees and their communities Prague: Statni zemedelske nakladatelstvi; 1953.

34. Gaussen H, Heywood VH, Chater AO: Pinus L. In Flora Europaea I Edited by: Tutin TG, Heywood VH, Burges NA, Valentine DH, Walters SM, Webb DA. Cambridge (UK): Cambridge University Press: 1964:32-35.

35. Pravdin LF: Scots Pine. Variation, intraspecific taxonomy and selection Jerusalem: Israel Program for Scientific Translations; 1969.

36. Krüssmann G: Handbuch der Nadelgehölze 2nd edition. Berlin: Parey P. 1983.

37. Giertych M, Oleksyn J: Studies on genetic variation in Scots pine (Pinus sylvestris L.) coordinated by IUFRO. Silvae Genet |992, 41:|33-| 43.

38. Sukacev VN: Dendrologija s osnovami lesnoi geobotaniki Moskow: Nauka; 1938

39. Tobolski J], Hanover JW: Genetic variation in the monoterpenes of Scotch pine. Forest Sci 197I, 17:293-299.
40. Forrest GI: Genotypic variation among native Scots Pine populations in Scotland based on monoterpene analysis. Forestry 1980, 53:10I-128.

4I. Gullberg U, Yazdani R, Rudin D: Genetic differentiation between adjacent populations of Pinus sylvestris. Silva Fenn 1982, 16:205-214.

42. Gullberg U, Yazdani R, Rudin D, Ryman N: Allozyme variation in Scots pine (Pinus sylvestris L.) in Sweden. Silvae Genet 1985, 34:193-201.

43. Kinloch BB, Westfall RD, Forrest GI: Caledonian Scots pine: origins and genetic structure. New Phytol 1986, 104:703-729.

44. Yazdani R, Nilsson JE: Cortical monoterpene variation in natural populations of Pinus sylvestris in Sweden. Scand J Forest Res 1986, I:85-93.

45. Lebreton P, Laracine-Pittet C, Bayet C, Lauranson J: Variation in polyphenol and taxonomy of Scots pine (Pinus sylvestris). Ann For Sci 1990, 47: I 17-130.

46. Dong J, Wagner DB: Taxonomic and population differentiation of mitochondrial diversity in Pinus banksiana and Pinus contorta. Theor Appl Genet 1993, 86:573-578.

47. Jaramillo-Correa JP, Bousquet J, Beaulieu J, Isabel N, Perron M, Bouillé $M:$ Cross-species amplification of mitochondrial DNA sequence-tagged-site markers in conifers: the nature of polymorphism and variation within and among species in Picea. Theor Appl Genet 2003, 106: I 353-1367.

48. Wolfe $\mathrm{KH}$, Li WH, Sharp PM: Rates of nucleotide subsitution vary greatly among plant mitochondrial, chloroplast, and nuclear DNAs. Proc Natl Acad Sci USA 1 987, 84:9054-9058.

49. Laroche J, Li P, Maggia L, Bousquet J: Molecular evolution of angiosperm mitochondrial introns and exons. Proc Natl Acad Sci USA 1997, 94:5722-5727.

50. Gros-Louis M-C, Bousquet J, Pâques LE, Isabel N: Species-diagnostic markers in Larix spp. based on RAPDs and nuclear, cpDNA, and mtDNA gene sequences, and their phylogenetic implications. Tree Genet Genomes 2005, I:50-63.

51. Sinclair WT, Morman JD, Ennos RA: Multiple origins for Scots pine (Pinus sylvestris L.) in Scotland: evidence from mitochondrial DNA variation. Heredity 1998, 80:233-240.

52. Sperisen C, Büchler U, Gugerli F, Mátyás G, Geburek T, Vendramin GG: Tandem repeats in plant mitochondrial genomes: application to the analysis of population differentiation in the conifer Norway spruce. Mol Ecol 200I, 1 0:257-263.

53. Bastien D, Favre JM, Collignon AM, Sperisen C, Jeandroz S: Characterization of a mosaic minisatellite locus in the mitochondrial DNA of Norway spruce (Picea abies (L.) Karst.). Theor Appl Genet 2003, 107:574-580.

54. Petit RJ, Duminil J, Fineschi S, Hampe A, Salvini D, Vendramin GG: Comparative organization of chloroplast, mitochondrial and nuclear diversity in plant populations. Mol Ecol 2005, |4:689-70|.

55. Muona O, Harju A: Effective population sizes, genetic variability, and mating system in natural stands and seed orchards of Pinus sylvestris. Silvae Genet 1989, 38:22I-228.

56. Wang $X-R$, Szmidt $A E$, Lindgren $D$ : Allozyme differentiation among populations of Pinus sylvestris (L.) from Sweden and China. Hereditas 1991, I 14:219-226.

57. Szmidt AE, Wang XR: Molecular systematics and genetic differentiation of Pinus sylvestris (L.) and P. densiflora (Sieb. et Zucc.). Theor Appl Genet 1993, 86: I59-165.

58. Goncharenko GG, Silin AE, Padutov VE: Allozyme variation in natural populations of Eurasian pines. III. Population structure, diversity, differentiation and gene flow in central and isolated populations of Pinus sylvestris L. in Eastern Europe and Siberia. Silvae Genet 1994, 43: I $19-132$.

59. Prus-Glowacki W, Bernard E: Allozyme variation in populations of Pinus sylvestris L. from a 1912 provenance trial in Pulawy (Poland). Silvae Genet 1994, 43: 132-138.

60. Prus-Glowacki W, Stephan BR: Genetic variation of Pinus sylvestris from Spain in relation to other European populations. Silvae Genet 1994, 43:7-14.

61. Szweykowski J, Prus-Glowacki W, Hrynkiewicz J: The genetic structure of Scots pine (Pinus sylvestris L.) population from the top of Szczeliniec Wielki Moutain, Central Sudetes. Acta Soc Bot Pol 1994, 63:3 I 5-324.

62. Naydenov KD, Tremblay FM, Alexandrov A, Fenton NJ: Structure of Pinus sylvestris L. populations in Bulgaria revealed by chlo- 
roplast microsatellites and terpenes analysis: Provenance tests. Biochem Syst Ecol 2005, 33:1226-1245.

63. Jaramillo-Correa JP, Beaulieu J, Ledig FT, Bousquet J: Decoupled mitochondrial and chloroplast DNA population structure reveals Holocene collapse and population isolation in a threatened Mexican-endemic conifer. Mol Ecol 2006, I 5:2787-2800.

64. Agúndez D, Degen B, von Wuehlisch G, Alía R: Multilocus analysis of Pinus halepensis Mill. from Spain: genetic diversity and clinal variation. Silvae Genet 1999, 48:173-178.

65. Carrión JS, Navarro C, Navarro J, Munuera M: The distribution of cluster pine (Pinus pinaster) in Spain as derived from palaeoecological data: relationships with phytosociological classification. Holocene 2000, 10:243-252.

66. Dobrinov I: Genetic and Selection of Forest Tree Sofia: Zemizdat; 1983.

67. Shaw KL: Conflict between nuclear and mitochondrial DNA phylogenies of a recent species radiation: What mtDNA reveals and conceals about modes of speciation in Hawaiian crickets. Proc Natl Acad Sci USA 2002, 99:16122-16127.

68. Ran JH, Wei XX, Wang XQ: Molecular phylogeny and biogeog. raphy of Picea (Pinaceae): Implications for phylogeographical studies using cytoplasmic haplotypes. Mol Phylogenet Evol 2006, $41: 405-419$

69. Eastwood WJ, Roberts N, Lamb HF, Tibby JC: Holocene environmental change in southwest Turkey: a palaeoecological record of lake and catchment-related changes. Quaternary $\mathrm{S}$ Rev 1999, | 8:67|-695

70. Nikolov N, Helmisaari H: Silvics of the circumpolar boreal forest tree species. In A Systems Analysis of the Global Forest Edited by: Shugart HH, Leemans R, Bonan GB. Cambridge (UK): Cambridge University Press; 1992:13-85.

7I. Ibrahim KM, Nichols RA, Hewitt GM: Spatial patterns of genetic variation generated by different forma of dispersal during range expansion. Heredity 1996, 77:282-291.

72. Seddon JM, Santucci F, Reeve NJ, Hewitt GM: DNA footprints of European hedgehogs, Erinaceus europaeus and $E$. concolor: Pleistocene refugia, postglacial expansion and colonization routes. Mol Ecol 2001, 10:2 187-2198.

73. van Zeist W, Bottema S: Late Quaternary vegetation of the Near East. In Beihefte zum Tubinger Atlas des vorderen orients Edited by: Verlag LR, Reihe A. Wiesbaden: Naturwissenshaften; 1991:I-I56.

74. Roberts N, Wright HE: Vegetational, lake level, and climatic history of the Near East and Southwest Asia. In Global climates since the last glacial maximum Edited by: Wright HE, Kutzbach JE, Webb T, Ruddiman WF, Street-Perrott FA, Bartlein PJ. Minneapolis: University of Minnesota Press; 1993:194-220.

75. Michaux JR, Libois R, Paradis E, Filippucci M-G: Phylogeographic history of the yellownecked fieldmouse (Apodemus flavicollis) in Europe and in the Near and Middle East. Mol Phylogenet Evol 2004, 32:788-798.

76. Cooper SJ, Ibrahim KM, Hewitt GM: Postglacial expansion and genome subdivision in the European grasshopper Chorthippus parallelus. Mol Ecol 1995, 4:49-60.

77. Demesure B, Comps B, Petit RJ: Chloroplast DNA phylogeography of the common beech (Fagus sylvatica L.) in Europe. Evolution 1996, 50:25I5-2520.

78. Giesecke T, Bennett KD: The Holocene spread of Picea abies (L.) Karst. in Fennoscandia and adjacent areas. J Biogeogr 2004, 3I:I523-I548.

79. Abbott RJ, Brochmann C: History and evolution of the arctic flora: in the footsteps of Eric Hultén. Mol Ecol 2003, I 2:299-3 I 3 .

80. Glebov FZ: Relations of Forest and Bog in the Taiga Belt Novosibirsk: Nauka; 1988.

81. Chernova GM, Mikhailov NN, Denisenko VP, Kozyreva MG: Some questions of paleogeography of Holocene of South Eastern Altai. Izvestia of All-Union Geographical Society 199|, 2: | 40-146.

82. Kremenetski CV, Lui KB, MacDonald GM: The late Quaternary dynamics of pines in northern Asia. In Ecology and Biogeography of Pinus Edited by: Richardson DM. Cambridge (UK): Cambridge University Press; 1998:95-106.

83. Willis KJ, Bennett KD, Birks HJB: The late Quaternary dynamics of pines in Europe. In Ecology and Biogeography of Pinus Edited by: Richardson DM. Cambridge (UK): Cambridge University Press; |998:107-121.

84. Moritz C: Defining 'Evolutionary Significant Units' for conservation. Trends Ecol Evol 1994, 9:373-375.
85. Moritz C: Strategies to protect biological diversity and the evolutionary process that sustain it. Syst Biol 2002, 51:238-254.

86. Clement M, Posada D, Crandall K: TCS: a computer program to estimate gene genealogies. Mol Ecol 2000, 9:1657-1660.

87. Weir BS: Genetic Data Analysis II Sunderland: Sinauer Associates; 1996.

88. Pons $O$, Petit RJ: Measuring and testing genetic differentiation with ordered versus unordered alleles. Genetics 1996, 144: 1237-I245

89. SAMOVA I.0: A program to define by a simulated annealing approach the genetic structure of populations [http:// cmpg.unibe.ch/software/samova/]

90. Dupanloup I, Schneider S, Excoffier L: A simulated annealing approach to define the genetic structure of populations. Mol Ecol 2002, I I:257| -258I.

91. Jeandroz S, Bastien D, Chandelier A, Du Jardin P, Favre JM: A set of primers for amplification of mitochondrial DNA in Picea abies and other conifer species. Mol Ecol Notes 2002, 2:389-391.

92. Soranzo N, Provan J, Powell W: An example of microsatellite length variation in the mitochondrial genome of conifers. Genome 1999, 42:|58-161.

93. Wu J, Krutovskii KV, Strauss SH: Abundant mitochondria genome diversity, population differentiation and convergent evolution in pines. Genetics 1998, 150:1605-1614.

94. Duff RJ, Nickrent DL: Phylogenetic relationships of land plants using mitochondrial small-subunit rDNA sequences. Am J Bot 1999, 86:372-386.

95. Demesure $B$, Sodzi N, Petit RJ: A set of universal primers for amplification of polymorphic non-coding regions of mitochondrial and chloroplast DNA in plants. Mol Ecol 1995, 4:|29-|3|.

Publish with BioMed Central and every scientist can read your work free of charge

"BioMed Central will be the most significant development for disseminating the results of biomedical research in our lifetime. "

Sir Paul Nurse, Cancer Research UK

Your research papers will be:

- available free of charge to the entire biomedical community

- peer reviewed and published immediately upon acceptance

- cited in PubMed and archived on PubMed Central

- yours - you keep the copyright

Submit your manuscript here:

http://www.biomedcentral.com/info/publishing_adv.asp
BioMedcentral 